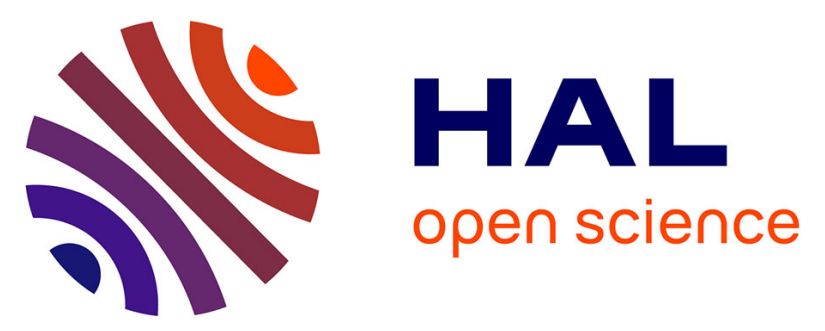

\title{
Book review: Holtorf, Cornelius, Archaeology is a Brand! The Meaning of Archaeology in Contemporary Popular Culture (Oxford: Archaeopress, 2007). ix + 184pp. ISBN $9781905739066 £ 14.99$ (paperback) \\ Katherine Pandora
}

\section{To cite this version:}

Katherine Pandora. Book review: Holtorf, Cornelius, Archaeology is a Brand! The Meaning of Archaeology in Contemporary Popular Culture (Oxford: Archaeopress, 2007). ix + 184pp. ISBN $9781905739066 £ 14.99$ (paperback). Public Understanding of Science, 2008, 17 (4), pp.507-508. 10.1177/09636625080170040603 . hal-00571137

\section{HAL Id: hal-00571137 \\ https://hal.science/hal-00571137}

Submitted on 1 Mar 2011

HAL is a multi-disciplinary open access archive for the deposit and dissemination of scientific research documents, whether they are published or not. The documents may come from teaching and research institutions in France or abroad, or from public or private research centers.
L'archive ouverte pluridisciplinaire HAL, est destinée au dépôt et à la diffusion de documents scientifiques de niveau recherche, publiés ou non, émanant des établissements d'enseignement et de recherche français ou étrangers, des laboratoires publics ou privés. 
that investigate the actual practice of doing genetic research are also largely absent from the volume (with some notable exceptions, such as Michael Fortun's ethnographic piece on Celera Genomics). This lacuna could potentially hinder public discussions about human genetics by reinforcing the perception that social and ethical issues exist only in the application of genetic knowledge, and not in the purportedly technical work of creating that knowledge that takes place within the laboratory. Philip Bereano's (pp.33-38) thought-provoking piece on the social values embedded in the Human Genome Project provides a needed corrective to this gap, but more attention to practice of science in the volume might help to facilitate "upstream" public engagement in the future directions of human genetic research as well as its applications (Willis and Wilsdon 2004).

However, these omissions could be easily remedied in a classroom setting by supplementing the volume with additional readings, and the stand-alone nature of these short, pithy chapters is ultimately, I believe, the volume's greatest strength. The individual entries could be easily taken apart and rearranged to highlight various themes, or integrated into existing syllabi. The sheer number of articles also ensures that no one viewpoint (or methodological approach) wins out over others. In a classroom setting, this volume would be invaluable to an instructor in need of accessibly written and provocative articles that could be used as the raw material for starting discussions on social and ethical issues in genetic research.

\section{References}

Lock, M., et al. (2006) When it runs in the family: putting susceptibility genes in perspective, Public Understanding of Science, 5, 277-300.

Nelkin, D., and Susan L., The DNA Mystique: The Gene as a Cultural Icon (University of Michigan Press, 1995).

Parthasarathy, S., Building Genetic Medicine: Breast Cancer, Technology, and the Comparative Politics of Health Care (MIT Press, 2007).

Willis, R., and Wilsdon, J., See-through science: why public engagement needs to move upstream. DEMOS Pamphlet (London: Demos, 2004).

\section{Nicole Nelson}

Department of Science and Technology Studies, Cornell University, USA
Holtorf, Cornelius, Archaeology is a Brand! The

Meaning of Archaeology in Contemporary

Popular Culture (Oxford: Archaeopress, 2007).

ix +184 pp. ISBN $9781905739066 £ 14.99$

(paperback).

In this high-spirited examination of archaeology's public image, Cornelius Holtorf sets out to illuminate current themes that mark the public understanding of archaeology as a scientific enterprise not simply to edify those who are interested in manifestations of science in popular culture, but also to encourage his professional colleagues to reflect upon the value, ethics, and politics of the relationships that exist (or not) between practitioners and the public. As he succinctly puts the issue, "Do archaeologists have social responsibilities and duties beyond contributing to academic enlightenment?" (p. 1). Holtorf believes that they do, and in Archaeology is a Brand! he asks his readers to put aside any tendencies they might have to interpret popular images merely as regrettable distortions of real science, seeking instead to leverage a discussion that will grant the public as having legitimate claims in producing scientific meaning. Indeed, his patient and thoughtful development of this issue is one that is a welcome and provocative starting point for scientists and scholars from any discipline who are interested in reflecting on questions about science and the public, not just those whose main interest is in archaeology.

In its format the book is an idiosyncratic melding of the professional and the popular: color cartoons bedeck the covers, the only internal illustrations are cartoons, and two running flipview cartoons are featured in the bottom margin (all of these are the work of Quentin Drew), an unusual choice in a book aimed at a scholarly audience, but one that fits the puckish challenges that Holtorf sends in good-natured seriousness to his readers. The use of frequent charts and sidebars gives the narrative something of the feel of a magazine article or of hypertext; this can at times be distracting, but in general these call-outs provide relevant highlighting and welcome amplifications. More conventionally, within the text, the chapters proceed in logical fashion to present Holtorf's argument, which engages with a number of formal research studies (including his own the book grows out of, in part, research funded by the European Commission at the Swedish 
National Heritage Board), along with additional materials and analyses that extend the background, examples, and interpretations further. The cartoon ambience might lead one to expect a somewhat superficial treatment of the topic but this is certainly not the case for the main text, which brings a substantive amount of source material and analysis into play, and the book is accompanied as well by the usual editorial accessories - a useful appendix of popular artifacts, a scholarly bibliography, and an index.

In the bulk of the book, Holtorf takes up such topics as archaeology in the mass media (particularly television, which he sees as the key conduit for the cultivation of public perceptions of archaeology); surveys and public opinion polling of what people think about archaeology; and the identification of key themes (the archaeologist as adventurer; as detective; as the deliverer of profound revelations; and as the caretaker of ancient cultural treasures). The examples are primarily drawn from Germany, Great Britain, and Sweden, although the United States figures in as well, due to the fact, in Holtorf's view, that "so much of European popular culture derives from there. . . The differences of the image of archaeology among these countries are not very large. Thanks to Hollywood and the global economy, most popular charcterisations apply more or less equally throughout the Western World" (p. 13). (Think of the Indiana Jones franchise as the definitive example here.) Holtorf's method is largely ethnographic, with attention to the existence of "the main opportunities where people who are not archaeologists themselves and go about their ordinary lives can hear or see something that strikes them as being 'archaeological.' That includes mass media, movies, advertising, toys, fictional and non-fictional literature, museums, and much more" (p. 13). Holtorf convincingly demonstrates the wide and deep public appeal of archaeology, which leads to his claim that, within the public sphere, archaeology is "a widely recognized, positively valued and well underpinned brand" (p. 15). The positive associations evoked by archaeology, interestingly, cut across the grain of the more generic popular culture representations of the scientist that contain negative stereotypes that veer off into the mad scientist image. The archaeologist, instead, is "seen as a hero and role model, competent and resourceful, through new discoveries and important revelations serving the interests of society and occasionally of humanity" (p. 62). These chapters make interesting inroads into the question of the nature and scope of the public presentation of archaeology, and will perhaps make the discipline of archaeology more appealing as a topic for scholars in sociology and history, who tend to focus on scientific subjects at the top of the disciplinary hierarchy (physics and laboratory biology).

If the purpose of the text was simply to present an overview of how archaeology and the public intersect - a welcome and interesting topic in itself - the book would end here. But these chapters are the essential grounding for Holtorf's two concluding chapters: "Strategies of Engagement" and "Public Archaeology Reconsidered." Holtorf outlines the appeal of "the Education Model" (which sees the public as having deficient perceptions that can be remedied by tutoring from professionals) and "the Public Relations Model" (which sees the public as a malleable entity which just needs to be lobbied for support in the proper way) and rejects them in favor of "the Democratic Model." This latter framework is one " which emphasises scientific responsibility and sustainable development and is based on participatory processes in which nonscientists predominate" (p. 107) and it is the way forward, Holtorf contends, to reconfiguring archaeology's relationships with the public such that good science is congruent with a defensible political philosophy that sees the public as neither ignorant nor incompetent but as "citizens who are essentially able to form their own mature opinions about difficult questions" (p. 108). But Holtorf asks for more than this recognition, arguing that "in a democratic system, science must answer to peoples' needs, address their desires and concerns and be subjected to political control by nonscientists - even though citizens may occasionally decide against what the experts would deem to be in their best interest" (p. 108). Readers in the United States, for example, might blanch at such a proposition given the current controversies over teaching intelligent design or the status of global warming as a scientific reality. But Holtorf raises serious questions that deserve serious consideration by the scientific community, if we are to think of scientific knowledge as belonging to all.

\section{Katherine Pandora}

History of Science Department, University of Oklahoma, USA. 